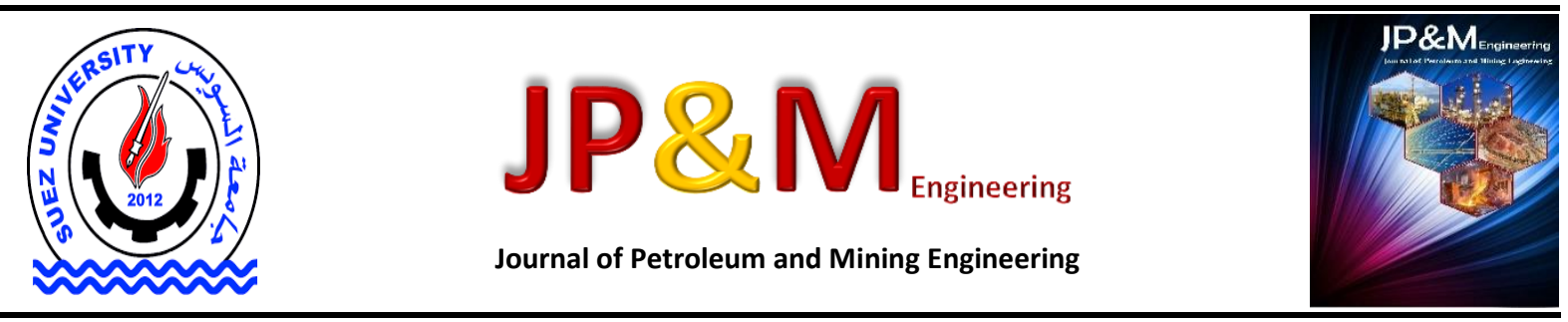

\title{
Crude Anti-accretion Additive from Petroleum Coke Distillate
}

Rubén Darío Vega Mejía, Gabriela Yasodhara Figueroa Velásquez, Jesús Eduardo Prosperi TorresaAffiliation and Universidad de Oriente, Engineering and Applied Sciences School, Petroleum Engineering Department. Campus Los Guaritos MonagasVenezuela

*rvega.udomonagas@gmail.com

\section{Article Info}

Received 12 Oct. 2021 Revised 1 Dec. 2021 Accepted 14 Jan. 2022

\section{Keywords}

Viscoelastic fluid, surfactant, coefficient of friction, distillate

\begin{abstract}
The adherence of crude oil to metal surfaces (accretion) during well drilling in the Orinoco Oil Belt (Venezuela) has led to the common use of lubricants in water-based drilling fluid. However, research is currently being carried out to also add a surfactant agent to the drilling fluid to mitigate this problem. The present investigation studied at laboratory level the petroleum coke's distillate use (CD) and its surfactant (CDS) for this purpose. Infrared (IR) Spectroscopy of both distillates exhibit that both fluids showed common spectra of surfactant agents. Likewise, its addition to a viscoelastic polymeric fluid contaminated with oil and petrolized sand brought the physical properties closer to the uncontaminated fluid (blank) values. When both fluids were studied as friction reducing agents (COF), they showed good capacity, reaching values associated with oil-based fluids. As accretion reducing agents, fluids with CDS and $C D$ at $1 \%$ concentration showed better performance than a commercial additive from a service company. Statistically, it was shown that there is no statistically significant difference between the $2 \%$ and $3 \% \operatorname{CDS}$ additive, so the recommended concentration is $2 \%$ CDS.
\end{abstract}

\section{Introduction}

According to the American Petroleum Institute within a standard measure wich is the API degrees, it is considered as light oil to those in the range between 30 and $40^{\circ}$, medium oil in the range from 22 to 29.9 ${ }^{\circ}$, heavy between 10 and $21.9^{\circ}$, extra heavy less than $10^{\circ}$ and unconventional hydrocarbons. Likewise, the crude oils viscosity varies according to the following: in conventional ones between 1 and $10 \mathrm{cP}$, in heavy and extra heavy below than $20 \mathrm{cP}$ and greater than $1,000,000.00 \mathrm{CP}$, due to the high viscosity of the aforementioned, its production, transportation and refining is difficult [1]. Of the total crude oil reserves in the world, $30 \%$ correspond to conventional crude, $15 \%$ to heavy crude, $25 \%$ to extra heavy crude and $30 \%$ to oil sands and bitumen [2].

In last two decades, heavy and extra heavy crude oils are being viewed as an alternative energy source, due to ecline in light crude oils production and the increase in energy demand [3]. As a consequence, efforts have been focused on the production of these crude oils. These resources exist in abundance and current technology allows its exploitation in profitable way [2].

Venezuela has the largest heavy and extra heavy crude reserves in the world, certified by the Organization of Petroleum Exporting Countries (OPEC) in 270,976 million barrels (MMB) [4]. Most of these reserves are located in the Orinoco Oil Belt (FPO in spanish), which consists of large extra heavy crude oil reservoirs $\left(8.5^{\circ} \mathrm{API}\right.$ and 1,300 $\mathrm{CP}$ viscosity at $127^{\circ} \mathrm{F}$ ). This has led to the FPO being known as one of the largest oil sand deposits, if not the largest in the world; it is located in southeastern Venezuela and has a 55,000 km2 area approximately [5].

In the FPO the oil wells are horizontal at depths no greater than 5000 feet TVD and aqueous fluids are used for drilling [5]. Also, the produced crude oil has high sulfur content, metals and the asphaltenefraction, chemical properties that make them unique [6]. A characteristic when drilling wells in the FPO is the stuck pipe incidents as well as excessive torque and drag, which have been common problems found while drilling horizontal wells. These incidents have been primarily attributed to high friction levels between the drillstring and the heavy oil sands [5].

Mixing heavy and extra heavy oil with unconsolidated sands causes them to adhere to the drillstring, casing and solids control equipment, this adherence is commonly known as oil accretion [7]. The traditional way to manage the accretion effect is to add a diluent (mineral oil or diesel; for example) to the drilling fluid system. The typical percentage of it is around 8 to $12 \% \mathrm{v} / \mathrm{v}$. It is used because it contains natural asphaltenes and surfactants that helps reducing the surface tension between the oil-based fluid 
and water (WBM), which addresses some accretion related problems [1].

Some efforts of Petróleos de Venezuela S.A through PDVSA-Intevep to solve this problem are associated with the MULTISURF $^{\circledR}$ technology use. This system is a surfactant-type additive that reduces abrasion in waterbased fluids densified with hematite, with which they supposed to improve inconveniences in the torque and drag increases in drilling, as well as the accretion problems in mixtures of heavy crude oil and sand on metallic surfaces, which generate difficulties in drilling due to their highly adhesive condition [9].

Previous research [5], [7] and [8] join the studies of INTEVEP [9] to reduce the accretion of crude oils, but using commercial surfactants. The use of a petroleum coke oil surfactant was born from the research "Release additive for drilling pipes based on petroleum coke distillate" [10] where favorable conditions for this use were observed.

The heavy crude oil production in the FPO has caused a surplus of petroleum coke, caused by the delay in the coking process to which the crude is subjected, accumulating $20,000 \mathrm{~T} / \mathrm{d}$ of petroleum coke [6]. Research carried out at the Universidad de Oriente has shown other unconventional uses for the petroleum coke, specifically as a drilling fluids additive (filter controller, rheological modifier, lost-circulation material, among others). However, for its use, the petroleum coke was subjected to the Soxhlet method, using Xylene as solvent, obtaining a distillate with which it was wanted to demonstrate its possible use as an antiacretion additive.

\section{Experimental}

This research was carried out in the drilling laboratory of the Petroleum Engineering Department of the Engineering and Applied Sciences School (EICA), The Guaritos Campus of Universidad de Oriente, Núcleo de Monagas. The used petroleum coke came from the José Antonio Anzoátegui petrochemical complex of Petróleos de Venezuela S.A (PDVSA) and the company PROAMSA supplied the additives for the fluids formulation.

\subsection{Characterization of the developed surfactant} additive

Initially, a coke crushing process was carried out in a hammer mill, then the product was passed through a No.20 sieve, and later the process for obtaining the oil from the petroleum coke distillate began, using the soxhlet extractor and Xylene as solvent (EPA3540C norm [10]. Then an atmospheric distillation process was carried out in order to separate the greatest amount of xylene from the petroleum coke oil.

In order to eliminate the solid particles present in the distillate it was centrifuged and filtered under vacuum. The surfactant was obtained by a coke distillate saponification process, which consisted of a mixture of a fatty acid (petroleum coke distillate) with an alkaline solution (KOH), as explained by Stephenson [11]. Subsequently, a Fourier Transform Infrared Spectroscopy was carried out, using a Perkin
Elmer FTIR 1600 equipment, which generated spectra and allowed to know the functional groups of the extracted coke distillate (CD) and the developed coke distillate surfactant (CDS).

1.2 Water-based drilling fluid physical properties determination with the formulated additive

This phase premise was to know the pollutants effect (crude oil and petrolized sand) on a blank fluid Commonly used fluid in FPO and the surfactant effects ( $C D$ and CDS) on the polluted fluid. For this, four (4) fluids types were studied, consisting of a blank, a control (contaminated), one with coke distillate (CD) and another with saponified coke distillate (CDS). The $\mathrm{CD}$ and $\mathrm{CDS}$ fluids had their additive concentration varied by $1 \%, 2 \%$ and $3 \% \vee / v$ and, like the control fluid, they were contaminated with oil and petrolized sands from the FPO. The water-based drilling fluids formulation used is shown in Table 1. The fluids were subjected to a dynamic aging process at $150^{\circ} \mathrm{F}$ and 100 psig for 16 hours. Subsequently, the physical properties were measured: fluid density, plastic viscosity, yield point, gels at 10 seconds and 10 minutes and filtering [12].

Table 1 Additives used in drilling fluid formulation

\begin{tabular}{cccc}
\hline Fluid & Blank & Control & CD, CDS \\
\hline Additive & Concentration & Concentration & Concentration \\
\hline Water (mL) & 301,75 & 301,75 & 301,75 \\
\hline $\begin{array}{c}\text { Xanthic } \\
\text { Gum (g) }\end{array}$ & 2 & 2 & 2 \\
\hline $\begin{array}{c}\text { Modified } \\
\text { starch (g) }\end{array}$ & 3 & 3 & 3 \\
\hline $\begin{array}{c}\text { Lubricant } \\
\text { (6\%) (mL) }\end{array}$ & 18 & 18 & 18 \\
\hline $\begin{array}{c}\text { Surfactant } \\
\text { (1\%, 2\% y } \\
\mathbf{3 \% ) ~ ( m L ) ~}\end{array}$ & - & - & $3,6,9$ \\
\hline $\begin{array}{c}\text { Calcium } \\
\text { carbonate } \\
\text { (g) }\end{array}$ & 45,89 & 45,89 & 45,89 \\
\hline $\begin{array}{c}\text { Caustic } \\
\text { potash }\end{array}$ & 1 & 1 & 1 \\
\hline $\begin{array}{c}\text { Petrolized } \\
\text { sand (g) }\end{array}$ & - & 40 & 40 \\
\hline Crude (g) & - & 40 & 40 \\
\hline
\end{tabular}

1.3 Capacity of CD and CDS additives study as friction reducing and anti-accretion agents

$\checkmark$ Friction reduction coefficient (COF) test: to determine the friction reduction coefficient, an OFITE lubricity meter was used and the Amanullah[13] method was applied. The metal / metal lubricity tester basically consists of a rotating steel ring against which a metal block can be compressed with varying loads using a torque wrench. In this way, blank, standard, DC and CDS lubricity fluids in their different concentrations was measured.

The used equipment allowed to apply the Amanullah [13] method which uses the following equations:

Correction factor $(\mathbf{C F})=\frac{\mathrm{T}_{\text {srdw }}}{\mathrm{T}_{\text {ardw }}}$

Coefficient of friction $(\mathrm{COF})=\frac{\mathrm{T}_{\mathrm{rm}} * \mathrm{CF}}{100 \mathrm{lb}}$

$\%$ Reduction COF $($ COFR $)=\frac{\mathrm{COF}_{\mathrm{fsp}}-\mathrm{COF}_{\mathrm{fcp}}}{\mathrm{COF}_{\mathrm{fsp}}} * 100$

Where

$\mathrm{T}$ srdw $=$ Standard torque reading of the calibration 
fluid

$\mathrm{T}$ ardw $=$ Actual torque reading of the calibration fluid.

$\mathrm{T} \mathrm{rm}=$ Torque reading of the fluid under study.

COFfsp $=$ Coefficient of friction of a fluid without antiaccretion additive.

COFfcp = Coefficient of friction of a fluid with antiaccretion additive.

$\checkmark$ Accretion test: the accretion test consisted of determining the drilling fluid adhesion against the oilcontaminated fluid samples. The test was carried out following the procedure described in the WM-GLHAL-BAR-LAB-TEST-015B BaraNhance Field Guide Line standard [14]. For this, the fluids with $C D$ and CDS were formulated under the same conditions and concentrations (Table 1), plus three other fluids with $1 \%, 2 \%$ and $3 \%(\% \vee / V)$ of commercial surfactant which were also contaminated with crude oil and petrolized sand $\left(8^{\circ} \mathrm{API}\right)$.

The test consisted of pouring the contaminated fluids into rolling cells to which a steel bar, already weighed, was introduced, simulating the drillstring's metallic elements, to evaluate the pollutants accretion on them. The cells were pressurized with $100 \mathrm{psig}$, to then be taken to a dynamic aging oven at a $120^{\circ} \mathrm{F}$ temperature for a 16 hours period. At the end, the dirty bar was weighed, and the accretion percentage of each fluid was calculated using the following equation:

$\%$ Accretion $=\left[\frac{\text { Dirty shirt }(\mathrm{g})-\text { Dry shirt }(\mathrm{g})}{\text { Dry shirt }(\mathrm{g})}\right] \times 100$

Once the fluid accretion percentages were obtained, a factorial experimental design was carried out, which included three blocks (fluids with: CD, CDS and commercial), three concentrations ( $1 \%, 2 \%$ and $3 \% \mathrm{~V} / \mathrm{V})$ and three repetitions wich represent the obtained accretion percentages. An ANOVA statistical test $(\alpha=0.05)$ was applied to establish whether there were significant statistical differences between the blocks under study, the concentrations and the block* concentration relationship, if the difference was positive, a Duncan test was applied to know which established these differences, for this the statistical software InfoStat was used.

\section{Results and discussion}

In the CD's spectrum (Fig. 1), it is observed that the value of $1278 \mathrm{~cm}^{-1}$ corresponds to $\mathrm{C}-\mathrm{O}-\mathrm{C}$ (Esters) vibrations, in the $1300-1400 \mathrm{~cm}^{-1}$ interval a $\mathrm{C}-\mathrm{H}$ bending of aliphatic hydrocarbons formed by carbon chains atoms in which there are no cyclic structures. At $1400 \mathrm{~cm}^{-1}$ a $\mathrm{C}-\mathrm{H}$ bending. At $1605 \mathrm{~cm}^{-1}$ can be noticed aromatics presence, at $1740 \mathrm{~cm}^{-1}$ the presence of carbonyl groups is detailed, in the $2800-$ 3000 range $\mathrm{cm}^{-1}$ a hydrogen carbon elongation appears, in the 3000 - 3100 range $\mathrm{cm}^{-1}$ a shoulder associated with unsaturated hydrocarbons such as (small amounts of aromatics) possibly xylene residues can be visualized, and at $3400 \mathrm{~cm}^{-1}$, the potbelly waves of primary aliphatic alcohols.

The behavior described in the spectroscopy and the presence of the mentioned compounds, suggest that this is a non-ionic surfactant itself, taking into consideration that these surfactants may contain: ethoxylated linear alcohols, ethoxylated alkyl phenols, fatty acid esters, derivatives of amines and amides, ethylene oxide-propylene oxide copolymers, polyalcohols and ethoxylated polyalcohols [15].polyalcohols and ethoxylated polyalcohols [15].

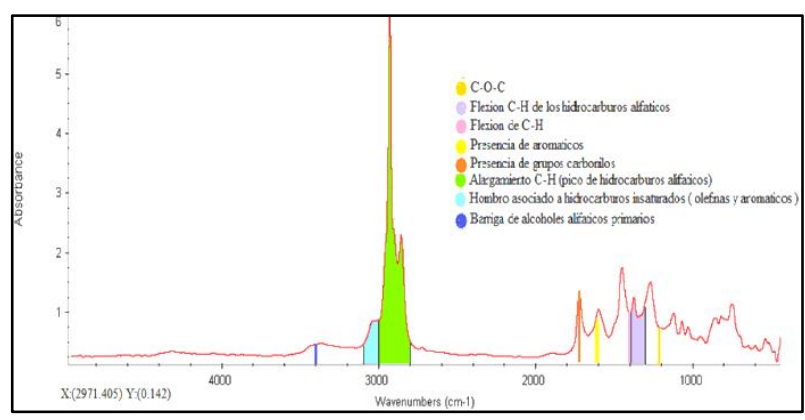

Figure 1 IR spectrum of coke distillate (CD)

The presence of carbonyl groups and aliphatic alcohols in the $C D$, deduces that there are carboxylic acids and esters in it, which allows us to assume that something similar to what happens during the ester's saponification can occur with the oil, that is, a chemical reaction between a fatty acid and a base or alkaline, obtaining salt as the main product. These compounds have the particularity of being amphipathic, also called amphiphilic, that is, they have a polar part and a nonpolar part (or nonpolar), so they can interact with different properties substances [15].

The ester's presence in the $C D$ is observed in the spectrum (Figure 1) at the $1278 \mathrm{~cm}^{-1}$ value which are shown as $\mathrm{C}-\mathrm{O}-\mathrm{C}$ vibrations, in addition the aliphatic alcohols presence at the $3400 \mathrm{~cm}^{-1}$ value can be detailed. These functional groups are described as a non-ionic surfactant type [2]

Likewise, an amphiphilic molecule will not react at all with a solvent that only contains one affinity. That is why the amphiphilic molecules show a strong tendency to migrate to the interfaces. Remembering that the word surfactant is used to denote a substance that has a surface or interfacial activity. Therefore, it can be said that this molecule is a surfactant

The CD spectrum obtained presented the same behavior with the one shown by Vega, et al [16] except between $1000 \mathrm{~cm}^{-1}$ and $1300 \mathrm{~cm}^{-1}$, where they reflected a not sufficiently resolved area, because it was not about a separate and pure organic substance, but a relatively complex mixture. This is an indication of centrifugation and vacuum filtration process efficiency that allowed to extract the solids present in the distillate.

In the CDS's spectrum (Fig. 2) it is observed the functional group presencecorresponding to carbonyl and amides at $1600 \mathrm{~cm}^{-1}$, between the $2800-3000$ $\mathrm{cm}-1$ interval a $\mathrm{C}-\mathrm{H}$ peak is detailed, in addition to the $\mathrm{H}-\mathrm{O}-\mathrm{H}$ presence between $3200-3600 \mathrm{~cm}^{-1}$ corresponding to water, which is a residual product of the saponification process, in this case is observed a 
notable decrease in the representative peak of $\mathrm{C}-\mathrm{H}$ vibrations as a consequence of the bonds breaking, resulting in a decrease in their concentrations.

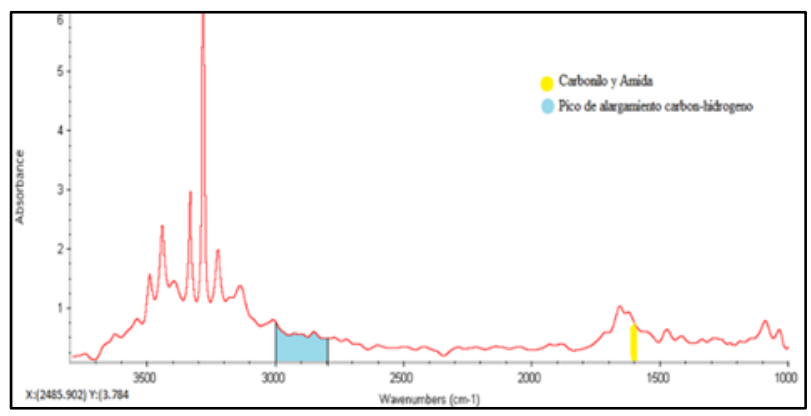

Figure 2 Coke Distillate Surfactant Spectrum (CDS)

Due to the carbonyl and amide groups existence, after the alkaline hydrolysis it can be inferred that the coke distillate surfactant is a cationic type surfactant. Linear chain cationic surfactants (s) are essentially the amines of certain amphoters [15]. These are used as emulsifiers in asphalt emulsions, in which they not only stabilize the stored emulsion, but also allow them to break easily as soon as there is contact with the rock aggregate.

The developed surfactant coincides with the cationic surfactants, which frequently contain one or more amino groups (-NH-) that can exist in protonated or quaternized form [17]. The spectra and its composition depends on the base and the process to obtain it.

The control fluid physical properties showed an increase compared to the blank (Table 2), due to pollutants present in it, and therefore a solids increase in drilling fluid Likewise, when adding the CD or CDS additives to the fluid, these decreased except for the filtering of the fluids with $C D$. This behavior was because of the increase in the liquid phase and the solid's phase constant maintenance.

Regarding to the obtained density in the blank fluid, this coincides with the reported values for a viscoelastic water-based drilling fluid for the Orinoco Oil Belt area [5]. However, they showed a higher addition in the amount of the weighing additive in the formulation to maintain the adequate hydrostatic pressure when surfactant was added.

Table 2 Physical properties of formulated fluids (standard, CD and CDS)

\begin{tabular}{|c|c|c|c|c|c|c|c|c|}
\hline \multirow{3}{*}{ Property } & \multirow{3}{*}{$\begin{array}{l}\text { Bla } \\
\text { nk }\end{array}$} & \multirow{3}{*}{$\begin{array}{l}\text { Cont } \\
\text { rol }\end{array}$} & \multicolumn{3}{|c|}{ Fluids with CD } & \multicolumn{3}{|c|}{$\begin{array}{l}\text { Fluids with } \\
\text { CDS }\end{array}$} \\
\hline & & & 1 & 2 & 3 & 1 & 2 & 3 \\
\hline & & & $\%$ & $\%$ & $\%$ & $\%$ & $\%$ & $\%$ \\
\hline Density (lpg) & 8,6 & 8,8 & 8,7 & 8,3 & 7,4 & 8,5 & 8,4 & 8,2 \\
\hline $\begin{array}{c}\text { Plastic } \\
\text { viscosity (cP) }\end{array}$ & 12 & 21 & 19 & 15 & 13 & 15 & 11 & 9 \\
\hline $\begin{array}{c}\text { Yield point } \\
(\mathrm{lb} / 100 \mathrm{ft} 2) \\
\end{array}$ & 37 & 44 & 39 & 31 & 25 & 32 & 28 & 21 \\
\hline $\begin{array}{l}\text { Gels at } 10 \mathrm{~s} \\
(\mathrm{lb} / 100 \mathrm{ft2})\end{array}$ & 10 & 25 & 16 & 13 & 9 & 8 & 6 & 5 \\
\hline $\begin{array}{l}10 \text { min gels } \\
\text { (lb / } 100 \mathrm{ft2} \text { ) }\end{array}$ & 14 & 28 & 17 & 15 & 10 & 9 & 7 & 6 \\
\hline $\begin{array}{c}\text { API Filtration } \\
(\mathrm{mL})\end{array}$ & 5 & 8 & $\begin{array}{c}10 \\
8\end{array}$ & $\begin{array}{c}13, \\
8\end{array}$ & $\begin{array}{c}15, \\
7\end{array}$ & 6,8 & 5,7 & 5 \\
\hline $\mathrm{pH}$ & 10 & 10,4 & 9,1 & 9 & 8,3 & $\begin{array}{c}10 \\
6\end{array}$ & $\begin{array}{c}11, \\
6\end{array}$ & $\begin{array}{c}12 \\
3\end{array}$ \\
\hline
\end{tabular}

An increase in the addition percentage of $C D$ and CDS led to a decrease in plastic viscosity not only for the increase in the liquid phase, but also due to dynamig aging to wich is was subjeted, where it was exposed to a temperature rise. The yielding point showed a higher value than the plastic viscosity, that is a common behavior in viscoelastic fluids where they present inverse rheology, as well as the plastic viscosity decreased with stronger CD and CDS concentrations. The obtained gels for both fluids were flat and brittle for all concentrations, this is characteristic of viscoelastic fluids, so the surfactants addition did not modify this property behavior.

The filtrate shown by the control fluid was considered high (>5 mL), regarding to the blank fluid. The filtering reflected dissimilar behaviors, while with the CD fluid the property increased with the percentage of surfactant; with the CDS fluid it decreased until reaching the desired value with $3 \%$ surfactant. This behavior was due to the addition of $\mathrm{KOH}$ to the $\mathrm{CD}$ to convert it to $\mathrm{CDS}$. The $\mathrm{KOH}$ supplied potassium and increased the $\mathrm{pH}$, the potassium addition helped to improve the filtering especially when subjected to dynamic aging.

When comparing the properties under study regarding to the field fluid presented by Andérico [5], who reported values of $11 \mathrm{cP}$ and $13 \mathrm{cP}$ (plastic viscosity), 36-39 lb / $100 \mathrm{ft}^{2}$ (yield point), 10/14 gels (lb / $100 \mathrm{ft}^{2}$ ) and $5.5 \mathrm{~mL}$ filtrate. It is observed the fluids that most agree with these values are $2 \%$ CD and $2 \%$ CDS.

The blank fluid presented a COF value of 0.236 and increased to 0.271 , when contaminated (control) water-based fluids treated with conventional lubricants generally produce friction coefficient values between 0.20 and 0.30 [3] (fig. 3). The CD addition managed to decrease it from 0.223 for $1 \%$ DC until 0.165 for $3 \% \mathrm{CD}$, while with CDS it decreased from $0.221(1 \%)$ to $0.159(3 \%)$. The obtained values are greater than 0.12 with the lubricant agent [5] and than 0.10 with the $3 \%$ ARC Eco-Lube agent [13]. However, these last two fluids were not contaminated, so it is possible to point out that the CD and CDS evidenced a good lubrication potential.

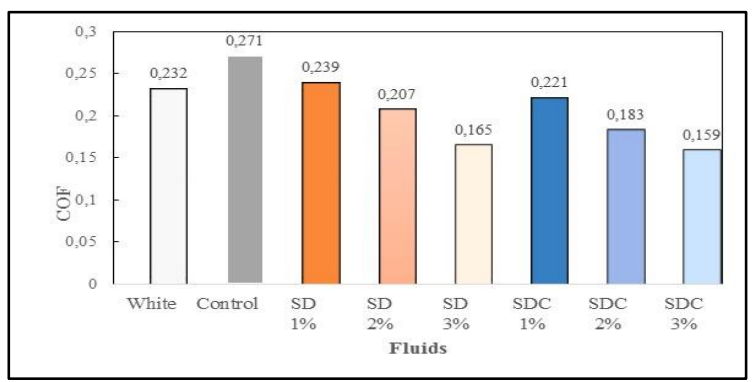

Figure 3 Blank, control, CD and CDS fluids COF

When the percentage of COF reduction was determined, $\mathrm{CD}$ decreases were observed (Fig. 4) in the range of 5.5 $34.3 \%$ and $17.7-42.8 \%$ for the blank fluid and the standard fluid, respectively. While for CDS it reflected ranges of $7.2-41.1 \%$ respect to the blan and $19.2-48.7 \%$ respect to the standard. Previous works using ARC EcoLube 3\% [4] achieved 50\% reductions. However, the obtained results for the $2 \%$ and $3 \%$ concentrations of CD and CDS are considered acceptable, because a minimum admissible COF reduction value must be at least between $20-25 \%$ of COF [4]. 


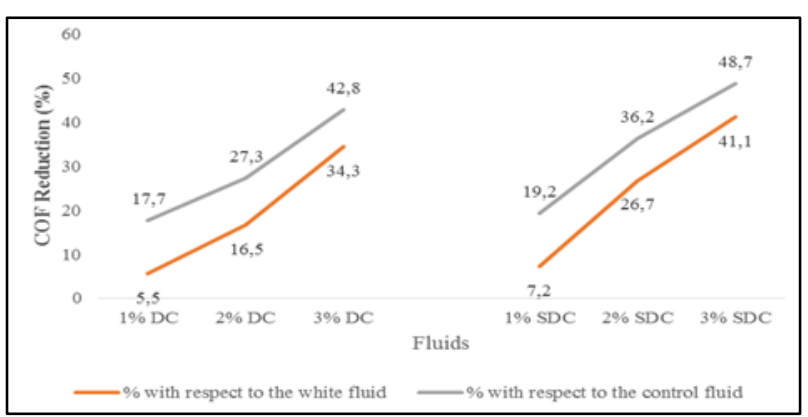

Figure 4 COF reduction percentage of the CD and CDS fluids with respect to the blank and the standard

As the accretion percentage is lower, the additive behavior as an anti-accretion agent will be better, figure 5 shows the average accretion values for the surfactants under study. Concerning to the control fluid, a $32.5 \%$ accretion was obtained, with the CD addition said value decreased to $12.9 \%$ for the $1 \% \mathrm{v} / \mathrm{v}$ concentration, after the increase to $2 \%$ and $3 \%$ concentrations it was observed a lower performance of the anti-accretion process $(20.2 \%$, $26.2 \%$ respectively), due to the fact that the fluids presented saturation, that is, the proportion of caustic potash within it was no longer sufficient to react with the coke oil and saponify it, causing the non-ionic characteristics of the $C D$ affected the petroleum molecules provoking them to fold on themselves, forming flocs which debilitate the interactions with the solvent.

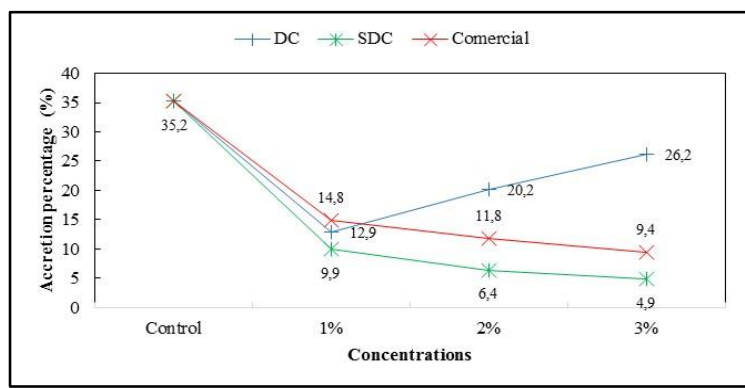

Figure 5 Behavior of the accretion percentage for CD, CDS and commercial additive

Concerning the fluid with CDS, it was observed that the $1 \%, 2 \%$ and $3 \% \mathrm{v} / \mathrm{v}$ concentrations presented average accretion percentage values of $9.9 \%, 6.34 \%$ and $4.96 \%$ respectively. This behavior was caused because the surfactant reacted in the drilling fluid, achieving the residual crude oil emulsification during dynamic aging, thus reducing the oil's adhesion on the metal surface. A visualization of the bar behavior before and after being subjected to the $3 \%$ CDS concentration is shown in Figure 6.

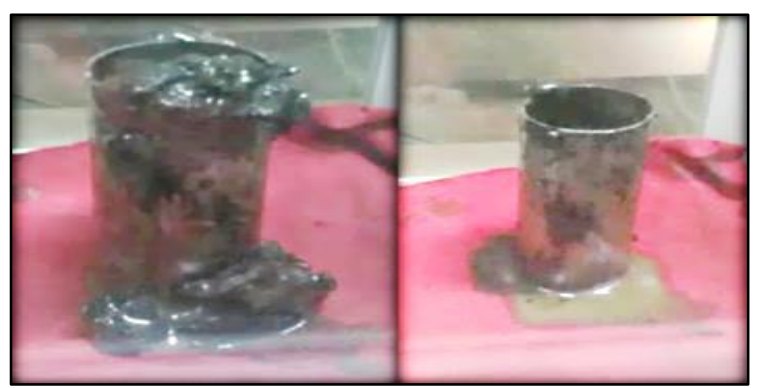

Figure 6 Bar's behavior before and after being subjected to the CDS ( $3 \%$ concentration)

The commercial surfactant also managed to decrease the accretion percentage as its concentration increased, the average accretion percentages were $14.9 \%$ ( $1 \%$ additive), $11.8 \%$ ( $2 \%$ additive) and $9.4 \%$ (3\% additive), but these are higher than those shown by the CDS and even higher than the $C D$ for the $1 \%$ concentration.

Another way to see the accretion reduction is to know the percentage of mass reduction adhered to the bar, in table 3 it is observed that for CD fluid $64.35 \%, 42.76 \%$ and $25.63 \%$ were obtained for $1 \%(\mathrm{~V} / \mathrm{V}), 2 \%(\mathrm{~V} / \mathrm{V})$ and $3 \%(\mathrm{~V} / \mathrm{V})$ concentrations respectively. While for CDS it began with a $71.88 \%$ reduction ( $1 \%$ concentration $\mathrm{V} / \mathrm{V}$ ) and increased to $81.99 \%$ ( $2 \%$ concentration) and obtained a maximum $85.91 \%$ value for $3 \%$ concentration. The commercial additive reduction values ranged between $57.73 \%$ (1\% concentration $\mathrm{V} / \mathrm{V}$ ) and $73.44 \%$ (3\% concentration $\mathrm{V} / \mathrm{V})$.

Table 3 Percentage of reduction of adhered mass with the use of CD, CDS and commercial additives

\begin{tabular}{cccc}
\hline & \multicolumn{3}{c}{ Concentration } \\
\cline { 2 - 4 } Additive & $\mathbf{1 \%}$ & $\mathbf{2 \%}$ & $\mathbf{3} \%$ \\
\hline DC & $63,35 \%$ & $42,76 \%$ & $25,63 \%$ \\
\hline SDC & $71,88 \%$ & $81,99 \%$ & $85,91 \%$ \\
\hline Commercial & $57,73 \%$ & $66,48 \%$ & $73,44 \%$ \\
\hline
\end{tabular}

The obtained results from mass reduction by $C D$ and CDS are consistent with those shown for four types of fluids with surfactant and lubricants used in the FPO [1], which reflected mass reduction values of $45.50 \%$ (fluid 1 ), $38.00 \%$ (fluid 2), $70.50 \%$ (fluid 3 ) and $55.80 \%$ (fluid 4). The above described shows a better efficiency in accretion reduction in fluids with $2 \%$ and $3 \%$ CDS.

The statistical study began with the factorial design development (Table 4) according to the proposed methodology.

Table 4 Factorial design

\begin{tabular}{ccccc}
\hline \multirow{2}{*}{ Block } & \multirow{2}{*}{ Concentration } & \multicolumn{4}{c}{ Accretion Percentage (AP) (\%) } \\
\cline { 2 - 5 } & & $\mathbf{A P}_{\mathbf{1}}$ & $\mathbf{A P}_{\mathbf{2}}$ & $\mathbf{A P}_{\mathbf{3}}$ \\
\hline \multirow{3}{*}{$\mathrm{CD}$} & $\mathrm{C}_{1}(1 \%)$ & 12.3 & 13.0 & 13.4 \\
\cline { 2 - 5 } & $\mathrm{C}_{2}(2 \%)$ & 19.4 & 21.0 & 20.1 \\
\cline { 2 - 5 } & $\mathrm{C}_{3}(3 \%)$ & 27.8 & 24.0 & 26.7 \\
\hline \multirow{3}{*}{$\mathrm{CDS}$} & $\mathrm{C}_{1}(1 \%)$ & 10.4 & 9.2 & 10.1 \\
\cline { 2 - 5 } & $\mathrm{C}_{2}(2 \%)$ & 7.3 & 5.7 & 6.1 \\
\cline { 2 - 5 } & $\mathrm{C}_{3}(3 \%)$ & 6.0 & 4.2 & 4.6 \\
\hline \multirow{3}{*}{ Commercial } & $\mathrm{C}_{1}(1 \%)$ & 14.5 & 15.4 & 14.7 \\
\cline { 2 - 5 } & $\mathrm{C}_{2}(2 \%)$ & 12.0 & 11.4 & 11.9 \\
\cline { 2 - 5 } & $\mathrm{C}_{3}(3 \%)$ & 9.7 & 9.3 & 9.2 \\
\hline
\end{tabular}

The variance analysis for the 27 samples (Table 5) presented a strong fit $(R 2=0.99)$ and a low variation of the data $(\mathrm{CV}<30)$ with a $\mathrm{p}$-value for the model, less than 0.0001 , therefore there are significant statistical differences.

Table 5 Variance analysis

\begin{tabular}{llllll}
\hline Variable & $\mathbf{N}$ & $\mathbf{R}^{\mathbf{2}}$ & $\mathbf{R}^{2}$ adj & $\mathbf{C . V}$ & $\mathbf{p}$-valor \\
\hline Accretion & 27 & 0,99 & 0,98 & 6,74 & $<0,0001$
\end{tabular}

When applying Duncan's test (Table 6), the presence of significant statistical difference between the blocks (different letters) was evidenced, where the best performance was obtained by the CDS (Letter A) (lowest mean accretion), followed by the commercial (Letter B) and later the CD (Letter C). 
It was also reflected that the best results were found when applying the maximum $3 \%$ concentration (Letter A) and the least favorable behavior was obtained with the $1 \%$ concentration (Letter B). The $2 \%$ concentration shows no differences from the other two concentrations (same letters).

When comparing the relation between the blocks by the concentrations (table 6) to know the additive that had the best performance regarding the reduction of accretion, it was found that these were the fluids with $3 \%$ and $2 \%$ CDS which did not present significant statistical differences between them (equal letters (A)), followed by commercial $3 \%$ and CDS $1 \%$ (letters B), commercial $2 \%$ and CD 1\% (letters C), commercial 1\% (letter D) and CD 2\% and $3 \%$ letters $\mathrm{E}$ and $\mathrm{F}$ respectively.

Table 6 Duncan Test

\begin{tabular}{|c|c|c|c|}
\hline & $\begin{array}{l}\text { CD } \\
\text { (I) }\end{array}$ & $\begin{array}{l}\text { CDS } \\
\text { (II) }\end{array}$ & $\begin{array}{c}\text { Comercial } \\
\text { (III) }\end{array}$ \\
\hline Block & $\mathrm{C}$ & $A$ & B \\
\hline \multirow{2}{*}{ Concentration } & $\mathrm{C}_{1}$ & $\mathrm{C}_{2}$ & $\mathrm{C}_{3}$ \\
\hline & $\mathrm{B}$ & $A, B$ & A \\
\hline \multirow{2}{*}{ Block } & \multicolumn{3}{|c|}{ Concentration } \\
\hline & $\mathrm{C}_{1}$ & $\mathrm{C}_{2}$ & $\mathrm{C}_{3}$ \\
\hline CD (Block I) & $\mathrm{C}$ & $E$ & $\mathrm{~F}$ \\
\hline CDS (Block II) & $\mathrm{B}$ & $A$ & $A$ \\
\hline Commercial (Block III) & $\mathrm{D}$ & $\mathrm{C}$ & B \\
\hline
\end{tabular}

The $C D$ and $C D S$ surfactants showed that by increasing their concentration they cause the fluids properties look like the blank one. In addition, they showed that they reduce COF to acceptable values, as well as the accretion percentage. Likewise, the statistical study showed that the best performance was presented by the CDS and that its use is independent of the concentration to be used ( $2 \%$ or $3 \%$ ), because the accretion reduction results for these two concentrations did not reflect significant statistical differences.

\section{Conclusions}

According to the results obtained, it evidenced according to the spectroscopy study, the coke distillate $(C D)$ turned out to be a non-anionic natural activated tensile, while the surfactant produced (CDS) was a cationic surfactant. Likewise, the $3 \% \mathrm{~V} / \mathrm{V}$ SDC addition to the viscoelastic drilling fluid brings the physical fluids properties (density, plastic viscosity, yield point, gels and filtrate) closer to the properties obtained for the viscoelastic blank fluid used in the Orinoco Oil Belt. Regarding the COF values obtained for the fluids with $C D$ and $C D S$ in their different concentrations under study, they demonstrated a good lubrication potential. Likewise, COF reduction percentages are above the minimum acceptable range $(20-25 \%)$, which makes it competitive in this property. In addition, from the point of view of the formulation, the best anti-accretion results were obtained with CDS surfactant at \% V/V concentration; from an operational point of view (fluids), CDS at $2 \%$ $\mathrm{V} / \mathrm{V}$ has the best surfactant presentation. Finally, there are no statistically significant differences in accumulation reduction between $2 \% \mathrm{~V} / \mathrm{V} \mathrm{CDS}$ and $3 \%$ $\mathrm{V} / \mathrm{V}$ CDS. Therefore, the recommended concentration is $2 \% \mathrm{~V} / \mathrm{V} \mathrm{CDS}$.

\section{Funding}

The research did not receive any specific grant from funding agencies in the public, commercial, or not-forprofit sectors.

\section{Conflicts of interest}

There are no conflicts to declare

\section{Acknowledgements}

The authors wish to thank Dr. Luis Isernia, Coordinator of the Molecular Sieves Laboratory for hearing his support in the development of spectroscopies.

\section{References}

[1] H. Alboudwarej et al. La importancia del petróleo pesado, Oilf. Rev. Schlumberger. 18 (2006) 38-59.

[2] A. Abarca, L Guzmán-Beckmann, J Castillo. Estudio del Efecto de Reductores de Viscosidad en Crudo Pesado, Revista Tecnológica - Espol. 32(1) (2020) 13-21. https://doi.org/10.37815/rte.v32n1.739

[3] International Energy Agency [IEA]. World energy outlook. IEA, Paris, 2012.

[4] Petróleos de Venezuela S.A [PDVSA], Venezuela posee las reservas de crudo más grande del mundo.http://www.pdvsa.com/index.php?opti on $=$ com content $\&$ view $=$ article \&id $=1501: 2423 \&$ catid=10\&ltemid=589\&lang=es. 2006 (Accessed July 14, 2021)

[5] L Andérico, E Larreal, M Ruíz, N Muñoz. Imp rovement of Drilling Operations on Horizontal Wells in the Orinoco Heavy Oil Belt, Venezuela. Paper presented at the SPE American and Caribbean Petroleum Engineering Conference, 2009, Cartagena. https://doi.org/10.2118/121697-MS

[6] M. Valera, E. D’Elia, J. De Jesús. An emerging and strategic vision of the use of Venezuelan delayed coke. Visión Tecnológica 16 (1-2) (2013) 7-17.

[7] D. Pernía, H. Ogalde, J. Arellano, S. Rosales y L. Márquez, Fluido de perforación utilizando un paquete de surfactantes. https://www.researchgate.net/publication/324 546016 Patente en Venezuela 2013000916 F LUIDO DE PERFORACION UTILIZANDO UN PA QUETE DE SURFACTANTES, 2013 (accessed August 2, 2021)

[8] J. Telles, L. Rojas, L. Díaz, N. Atencio, A. Cortés, E. Calderón, J. Dorca, J. Peñaranda, V. Navarro, C. Ydrogo, L. Mata, E. Correa y D. Páez, Successful Experience of Water-Base Drilling Fluid Products Working in Synergy to Optimize Drilling Operations for Horizontal Wells in Extra-Heavy Oil Reservoir. Paper presented at the SPE East Oil \& Gas Conference, 2017, Kingdom of Bahrain. https://doi.org/10.2118/121697-MS

[9] Petroleós de Venezuela S.A [PDVSA], Investigadores de PDVSA INTEVEP publicaron 
resultados de trabajo en libro de surfactantes. http://www.pdvsa.com/index.php?option=com content\&view=article\&id=8083:investigadores -de-pdvsa-intevep-publicaron-resultados-detrabajo-en-libro-desurfactantes\&catid=10\&/temid=589\&lang=es, 2015 (Accessed July 21, 2021)

[10] Environmental Protection Agency [EPA]. Soxhelt extraction, part of test methods for evaluating solids waste, physical/ chemical methods (Método 3540C). EPA, Washington, 2015.

[11] R. Stephenson. Introducción a los procesos químicos industriales. Continental, Ciudad de México, 1980.

[12] American Petroleum Institute [API], Norma API RP 13B-1. Recommended pratice for field testing wáter based fluids drilling fluids. API, Houston, 2005.

[13] M Amanullah. Coefficient of friction reducing efficiency of ARC Eco-Lube, Paper presented at the IADC/SPE Asia Pacific Drilling Technology Conference, 2016, Singapore. https://doi.org/10.2118/180504-MS

[14] Halliburton. WM-GL-HAL-BAR-LAB-TES-015B BaraNhance Field Guide Line. Baroid, Dalas, 2010.

[15] J. Salager, A. Fernandez. Surfactantes Catiónicos. Episte, Mérida, 2004.

[16] R. Vega, O. Rodríguez, A. Rodríguez. Aditivo liberador de tuberías de perforación a base de destilado de coque de petróleo, Veritas Et Scientia. $9 \quad$ (2) (2020) 232-242. https://doi.org/10.47796/ves.v9i2.398

[17] R. Mercado, J. Salager, M. Celis, J. Avendaño. Volumetría de determinación espectrofotométrica de un surfactante catiónico tipo diamina, mediante la formación de un complejo coloreado, Revista Ciencia $e$ Ingeniería. 31(3) (2010) 177-182.

[18] H. Darley, G. Gray. Composition and Properties of Drilling and Completion Fluids. Gulf Publishing, Co, Houston, 1991. 